\title{
STUDIES ON THE IMMUNE RESPONSE OF THE RHEUMATIC SUB- JECT AND ITS RELATIONSHIP TO ACTIVITY OF THE RHEU- MATIC PROCESS. VII. SPLENECTOMY IN RELATION TO THE DEVELOPMENT OF RHEUMATIC ACTIVITY ${ }^{1}$
}

\author{
BY ALVIN F. COBURN AND RUTH H. PAULI
}

\begin{abstract}
(From the Department of Medicine, College of Physicians and Surgeons, Columbia University, and the Presbyterian Hospital, New York City)
\end{abstract}

(Received for publication June 3, 1935)

Preceding papers have shown $(1,2,3,4,5)$ that in the rheumatic subject one factor essential for the development of acute rheumatism is the magnitude of the immune response to hemolytic streptococcus infection. The mechanism involved in the rheumatic process is unknown. The present paper deals with an attempt to diminish the patient's antibody production for the purpose of modifying the rheumatic process, and with observations on the relation of the spleen to rheumatic activity.

A number of investigators $(6,7,8)$ interested in the mechanism of immune reactions are agreed that the spleen plays a rôle in the fixation of antigen and in the production of antibody, and that splenectomy may inhibit antibody formation under certain conditions. Clinical observers have established the effectiveness of splenectomy in certain hemorrhagic disorders. Since the tendency to hemorrhage is a common characteristic of rheumatic activity, which occurs at the time that the immune response is evoked, it seemed possible that splenectomy might modify the responses of the rheumatic subject to infection. Splenectomy was performed on a selected group of children who have subsequently been kept under close observations. The findings are discussed in this paper.

\section{PROCEDURE}

Twenty children with rheumatic heart disease were chosen for this study. All were members of intelligent, cooperative families. All had been under the authors' care for a period of two to six years. The group consisted of fourteen girls and six boys between the ages of five and twelve. They were chosen because they were believed to be susceptible subjects and were of an extremely

1 The work reported in this communication was carried out under The W. K. Kellogg Foundation. vulnerable age. Twelve were of Irish extraction, five of Italian, the remainder of Hebrew, Scotch and German parentage. To all appearances, the entire group was in good condition at the time of operation in the summer of 1932.

Each patient was admitted to the wards of the Babies Hospital for complete physical examination. Laboratory tests including blood count, blood sedimentation rate, electrocardiographic tracing, $\mathrm{x}$-ray of heart and serological tests were made just prior to operation and at frequent intervals thereafter.

All of the operations were performed between the months of July and October, at a time when the incidence of respiratory infection was minimal. The patients were kept on the wards for at least three weeks and then given convalescent care. There was no operative mortality.

Results two years after recovery from operation

All of these twenty patients have been kept under close observation since splenectomy. Throat cultures and blood studies (9) have been made at frequent intervals. During the early part of this period all of the children, with the exception of D. K. (page 786), appeared in good health. The blood findings were essentially normal except for a persistent leukocytosis in some instances. During the first two years following splenectomy, ten individuals were known to be infected with hemolytic streptococcus; others had upper respiratory infections from which cultures were not obtained. The follow-up records are summarized in Table I.

Table I is divided into two parts. In Section A are presented eleven subjects ${ }^{2}$ who appeared to escape rheumatic fever during the period of ob-

${ }^{2}$ Patient J. H. has subsequently contracted hemolytic streptococcus pharyngitis and developed a fulminating rheumatic attack accompanied by rise in antistreptolysin titer to 1000 units. 
TABLE I

Summary of clinical courses of rheumatic subjects for two years following splenectomy

\begin{tabular}{|c|c|c|c|c|c|c|c|c|c|}
\hline \multirow{2}{*}{ :ّ̊̆ } & \multirow{2}{*}{ Name } & \multirow{2}{*}{ Number } & \multirow{2}{*}{ Age. } & \multicolumn{3}{|c|}{ 1933-Spring months } & \multicolumn{3}{|c|}{ 1934-Spring months } \\
\hline & & & & $\begin{array}{l}\text { Infec- } \\
\text { tion }\end{array}$ & $\begin{array}{l}\text { Clinical } \\
\text { condition }\end{array}$ & $\begin{array}{l}\text { Antistrep- } \\
\text { tolysin titers }\end{array}$ & $\begin{array}{l}\text { Infec- } \\
\text { tion }\end{array}$ & $\begin{array}{l}\text { Clinical } \\
\text { condition }\end{array}$ & $\begin{array}{l}\text { Antistrep- } \\
\text { tolysin titers }\end{array}$ \\
\hline \multirow{6}{*}{$\boldsymbol{A}$} & M.F. & 294481 & $\begin{array}{c}\text { years } \\
9\end{array}$ & & $\begin{array}{l}\text { Good health until } \\
\text { sudden death from } \\
\text { poliomyelitis }\end{array}$ & $\begin{array}{c}\text { units per cc. } \\
100\end{array}$ & & & units per cc. \\
\hline & $\begin{array}{l}\text { D.H. } \\
\text { M.K. } \\
\text { J.H. }\end{array}$ & $\begin{array}{l}294421 \\
258190 \\
285598\end{array}$ & $\begin{array}{l}7 \\
9\end{array}$ & & $\begin{array}{l}\text { Good health } \\
\text { Good health } \\
\text { Good health }\end{array}$ & $\begin{array}{r}125 \\
68 \\
167\end{array}$ & & $\begin{array}{l}\text { Good health } \\
\text { Good health } \\
\text { Good health }\end{array}$ & $\begin{array}{r}100 \\
100 \\
83\end{array}$ \\
\hline & V.B. & 263099 & 12 & $\begin{array}{l}\text { Hemolytic } \\
\text { streptococcus } \\
\text { pharyngitis }\end{array}$ & $\begin{array}{l}\text { Good health; rheu- } \\
\text { matic attack appar- } \\
\text { ently aborted }\end{array}$ & 63 & & Good health & 100 \\
\hline & $\begin{array}{l}\text { M.G. } \\
\text { D.D. } \\
\text { T.M. }\end{array}$ & $\begin{array}{r}309919 \\
83923 \\
290518\end{array}$ & 11 & & $\begin{array}{l}\text { Good health } \\
\text { Good health } \\
\text { Good health } \\
\end{array}$ & $\begin{array}{l}83 \\
25 \\
50\end{array}$ & & $\begin{array}{l}\text { Good health } \\
\text { Good health } \\
\text { Good health }\end{array}$ & $\begin{array}{l}143 \\
143 \\
100 \\
\end{array}$ \\
\hline & $\overline{\text { C.T. }}$ & 345102 & 11 & & Good health & 125 & $\begin{array}{l}\text { Hemolytic } \\
\text { streptococcus } \\
\text { pharyngitis }\end{array}$ & 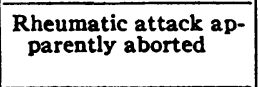 & 333 \\
\hline & E.C. & $\begin{array}{l}306278 \\
264761\end{array}$ & $\begin{array}{r}10 \\
9\end{array}$ & & $\begin{array}{l}\text { Good health } \\
\text { Good health }\end{array}$ & $\begin{array}{l}71 \\
63\end{array}$ & & $\begin{array}{l}\text { Good health } \\
\text { Good health }\end{array}$ & $\begin{array}{r}83 \\
125\end{array}$ \\
\hline \multirow{9}{*}{$\boldsymbol{B}$} & $\overline{\text { G.M. }}$ & 80995 & 12 & $\begin{array}{c}\text { Hemolytic } \\
\text { streptococcus } \\
\text { pharyngitis }\end{array}$ & $\begin{array}{l}\text { Carditis and poly- } \\
\text { arthritis }\end{array}$ & 500 & & $\begin{array}{r}\text { Continued progressive } \\
\text { carditis terminating } \\
\text { in death from acute } \\
\text { dilatation, June } 1934 \\
\end{array}$ & 500 \\
\hline & D.A. & 81423 & 8 & & Good health & 100 & $\begin{array}{l}\text { Hemolytic } \\
\text { streptococcus } \\
\text { pharyngitis }\end{array}$ & $\begin{array}{l}\text { Carditis and polyar- } \\
\text { thritis with recovery }\end{array}$ & 1000 \\
\hline & A.H. & 262080 & 12 & & Good health & 143 & $\begin{array}{c}\text { Hemolytic } \\
\text { streptococcus } \\
\text { pharyngitis }\end{array}$ & $\begin{array}{l}\text { Fulminating pancar- } \\
\text { ditis terminating in } \\
\text { death, May } 1934\end{array}$ & 1250 \\
\hline & S.G. & 346005 & 11 & $\begin{array}{l}\text { Hemolytic } \\
\text { streptococcus } \\
\text { pharyngitis }\end{array}$ & $\begin{array}{l}\text { Carditis and poly- } \\
\text { arthritis }\end{array}$ & 83 & & $\begin{array}{l}\text { Recovered from rheu- } \\
\text { matic attack }\end{array}$ & 200 \\
\hline & H.D. & 69558 & 10 & & Good health & 50 & $\begin{array}{l}\text { Hemolytic } \\
\text { streptococcus } \\
\text { pharyngitis }\end{array}$ & $\begin{array}{l}\text { Carditis and polyar- } \\
\text { arthritis }\end{array}$ & 333 \\
\hline & $\overline{\text { D.K. }}$ & 234004 & 6 & & $\begin{array}{l}\text { Continued activity, } \\
\text { severe carditis }\end{array}$ & 500 & $\begin{array}{c}\text { Hemolytic } \\
\text { streptococcus } \\
\text { pharyngitis }\end{array}$ & Mild symptoms & 250 \\
\hline & D.C. & 313902 & 11 & & Good health & 50 & $\begin{array}{l}\text { Tonsillitis in } \\
\text { Chicago }\end{array}$ & $\begin{array}{l}\text { Carditis and polyar- } \\
\text { thritis }\end{array}$ & 500 \\
\hline & E.B. & 299767 & 11 & $\begin{array}{l}\text { Hemolytic } \\
\text { streptococcus } \\
\text { pharyngitis }\end{array}$ & $\begin{array}{l}\text { Mild symptoms } 2 \\
\text { months later }\end{array}$ & $\begin{array}{l}100 \\
250\end{array}$ & & Good health & 55 \\
\hline & D.M. & 83833 & 6 & $\begin{array}{l}\text { Hemolytic } \\
\text { streptococcus } \\
\text { pharyngitis }\end{array}$ & $\begin{array}{l}\text { Good health except } \\
\text { for erythema nodo- } \\
\text { sum } 6 \text { months later }\end{array}$ & 167 & & Good health & 167 \\
\hline
\end{tabular}

servation. Two of them contracted throat infections but did not develop any symptoms or signs of rheumatic activity. The organisms associated with these infections, however, produced little or no detectable soluble toxin; that is, they were strains which are generally ineffective (3).

Section B of Table I deals with nine patients who developed rheumatic manifestations. Two subjects who contracted hemolytic streptococcus infections within six months after splenectomy responded with unusually mild attacks. Patient
E. B. (on the tenth day after pharyngitis) developed fever and other symptoms of only five days' duration. The antistreptolysin titer remained constant at 100 units. Two months later the patient experienced another short febrile period accompanied by a rise in antistreptolysin titer. to 250 units. Patient S. G. also contracted hemolytic streptococcus pharyngitis in December 1932, and developed a rheumatic attack which, however, subsided spontaneously in six days. The antistreptolysin titer remained constant at 83 
units. $^{3}$ The organisms, however, persisted in the throat flora in great numbers. During the spring of 1934 the patient again had mild rheumatic symptoms. Hemolytic streptococcus was predominant in the throat flora; and the antistreptolysin titer went up to 200 units. The organisms associated with the throat infections in these two patients were strong toxin producers.

During the next eighteen months, six other patients were infected with effective strains of hemolytic streptococcus. These individuals all developed typical attacks with characteristic antistreptolysin curves. There was nothing to differentiate these recrudescences from those usually seen in rheumatic subjects.

Three of the group of twenty individuals died. Patient N. F. appeared free of active rheumatism in July, 1933, and had an antistreptolysin titer of 100 units, when she contracted bulbar poliomyelitis. The autopsy showed an old adherent pericarditis and mitral stenosis but no fresh rheumatic lesions and no Aschoff bodies. Patient G. M. died suddenly while apparently convalescent in the country. He had experienced prolonged smouldering activity and had an antistreptolysin titer between 333 and 500 units. No postmortem examination was made. Patient A. H., one of The Pelham Home children, died during a fulminating rheumatic attack, with an antistreptolysin titer of 1250 units (2). The autopsy revealed widespread rheumatic lesions, edematous and hemorrhagic lymph nodes and extensive hemorrhage.

In summary, the rheumatic attacks which developed within six months after splenectomy seemed less severe than usual. By the end of one year, however, all of the splenectomized children responded in the customary way, with the typical clinical and pathological picture of acute rheumatism.

\section{Immediate effect of splenectomy}

Previous experience had led to the belief that splenectomy during active rheumatism might be extremely dangerous. In 1929, a twelve year old

3 The occurrence of a rheumatic attack after streptococcus pharyngitis and not accompanied by rise in antistreptolysin titer has been previously recorded in only two instances. colored boy, Number 80516, who had undergone splenectomy for purpura died suddenly shortly after the spleen was delivered. At the time, death was attributed to hemorrhage. Aschoff bodies found at autopsy demonstrated that he was a rheumatic subject, and the auscultatory cardiac signs during life, in conjunction with the electrocardiographic finding of prolonged conduction time $(\mathrm{P}-\mathrm{R}=0.23$, and $\mathrm{ST}$ interval elevated in Leads 2 and 3 ), indicated that the rheumatic process was active. This experience suggested that splenectomy in a subject with active rheumatism might possibly intensify the activity of the disease process.

The first members of the above group of patients chosen for splenectomy were therefore individuals who had been free of infection and had experienced no rheumatic manifestations for a period of at least one year. Their postoperative courses are summarized in Table II, Group A.

These individuals, who were clinically quiescent and who had appeared to be free of respiratory infection for a long time, underwent splenectomy without untoward effect. There was little or no postoperative rise in the leukocyte count. The electrocardiograms were all normal before and on repeated examination after operation. The antistreptolysin titer was over 100 units in only three of the individuals before operation, and there was no change in titer following operation. So far as could be determined, the rheumatic process was quiescent in these subjects before and after splenectomy.

Four patients are presented in a second group. These individuals had contracted respiratory infections during the spring but were in good condition at the time of operation. The antistreptolysin titers, however, were all above 100 units. Their courses are summarized in Table II, Group B.

These four patients had mild postoperative courses; however, all developed changes suggesting the possibility of slight rheumatic activity. Three had a postoperative leukocytosis; one, fever; and three, alteration in the electrocardiographic tracings. There was no change in the antistreptolysin titers.

Five patients who had contracted hemolytic streptococcus infection and who had experienced 
TABLE II

The reactions of a group of 20 rheumatic subjects to splenectomy

\begin{tabular}{|c|c|c|c|c|c|c|c|c|}
\hline Group & Name & $\begin{array}{c}\text { Recent hemolytic } \\
\text { streptococcus infection }\end{array}$ & $\begin{array}{l}\text { Clinical } \\
\text { state }\end{array}$ & $\begin{array}{c}\text { Throat } \\
\text { flora }\end{array}$ & W.B.C. & W.B.C. & $\begin{array}{c}\text { Anti- } \\
\text { strepto- } \\
\text { lysin } \\
\text { titer } *\end{array}$ & Symptoms \\
\hline A. & $\begin{array}{l}\text { J.H. } \\
\text { C.T. } \\
\text { T.O. } \\
\text { D.M. } \\
\text { N.F. } \\
\text { M.G. } \\
\text { D.H. } \\
\text { E.B. } \\
\text { D.D. } \\
\text { D.G. }\end{array}$ & $\begin{array}{l}\text { None recognized } \\
\text { None recognized } \\
\text { None recognized } \\
\text { None recognized } \\
\text { None recognized } \\
\text { None recognized } \\
\text { None recognized } \\
\text { None recognized } \\
\text { None recognized } \\
\text { None recognized } \\
\text { None recognized }\end{array}$ & $\begin{array}{l}\text { Apparently quiescent } \\
\text { Apparently quiescent } \\
\text { Apparently quiescent } \\
\text { Apparently quiescent } \\
\text { Apparently quiescent } \\
\text { Apparently quiescent } \\
\text { Apparently quiescent } \\
\text { Apparently quiescent } \\
\text { Apparently quiescent } \\
\text { Apparently quiescent } \\
\text { Apparently quiescent }\end{array}$ & $\begin{array}{l}\text { Normal } \\
\text { Normal } \\
\text { Normal } \\
\text { Normal } \\
\text { Normal } \\
\text { Normal } \\
\text { Normal } \\
\text { Normal } \\
\text { Normal } \\
\text { Normal } \\
\text { Normal }\end{array}$ & $\begin{array}{l}5,900 \\
6,650 \\
6,400 \\
7,700 \\
8,150 \\
7,500 \\
8,100 \\
7,500 \\
7,000 \\
6,500 \\
9,400\end{array}$ & $\begin{array}{r}10,050 \\
9,600 \\
12,150 \\
10,000 \\
6,850 \\
9,000 \\
8,100 \\
9,250 \\
8,200 \\
16,850 \\
14,000\end{array}$ & $\begin{array}{c}\text { units } \\
\text { per cc. } \\
100 \\
250 \\
50 \\
100 \\
33 \\
200 \\
250 \\
100 \\
50 \\
50 \\
50\end{array}$ & $\begin{array}{l}\text { None } \\
\text { None } \\
\text { None } \\
\text { None } \\
\text { None } \\
\text { None } \\
\text { None } \\
\text { None } \\
\text { None } \\
\text { None } \\
\text { None }\end{array}$ \\
\hline c. & $\begin{array}{l}\text { D.K. } \\
\text { G.M. } \\
\text { H.D. } \\
\text { V.B. } \\
\text { D.A. }\end{array}$ & $\begin{array}{l}\text { Pharyngitis } 6 \text { months } \\
\text { previously } \\
\text { None recognized } \\
\text { Pharyngitis } 10 \text { weeks } \\
\text { previously } \\
\text { Pharyngitis } 6 \text { months } \\
\text { previously } \\
\text { Pharyngitis } 8 \text { months } \\
\text { previously }\end{array}$ & $\begin{array}{l}\text { Persistent mildly ac- } \\
\text { tive disease } \\
\text { Apparently quiescent } \\
\text { Mild activity subsid- } \\
\text { ing } \\
\text { Apparently quiescent } \\
\text { Apparently quiescent }\end{array}$ & $\begin{array}{l}\text { Normal } \\
\text { Normal } \\
\text { Normal } \\
\text { Normal } \\
\text { Normal }\end{array}$ & $\begin{array}{r}6,000 \\
10,450 \\
5,900 \\
7,250 \\
13,350\end{array}$ & $\begin{array}{l}31,000 \\
20,000 \\
26,250 \\
18,450 \\
16,050\end{array}$ & $\begin{array}{l}500 \\
167 \\
111 \\
143 \\
167\end{array}$ & $\begin{array}{l}\text { Severe pancarditis, beginning } 24 \text { hours } \\
\text { after operation, lasting } 19 \text { days, almost } \\
\text { fatal. } \\
\text { Mild reumatic attack with polyarthri- } \\
\text { tis beginning } 48 \text { hours postoperative. } \\
\text { Joint pains } 6 \text { days postoperative. Fol- } \\
\text { lowed by gross hematuria. } \\
\text { Severe epistaxis and fever } 4 \text { days post- } \\
\text { operative. } \\
\text { Epistaxis } 2 \text { nd and } 4 \text { th days postopera- } \\
\text { tive. }\end{array}$ \\
\hline
\end{tabular}

* These titers were the same as the preoperative titers.

rheumatism during the spring months were operated on in the late summer or fall. At that time the clinical findings and blood studies indicated that the disease process was either quiescent or subsiding. The antistreptolysin titers were all above 100 units. The findings are presented in Table II, Group C.

These five individuals experienced a rheumatic recrudescence after splenectomy. The onset of

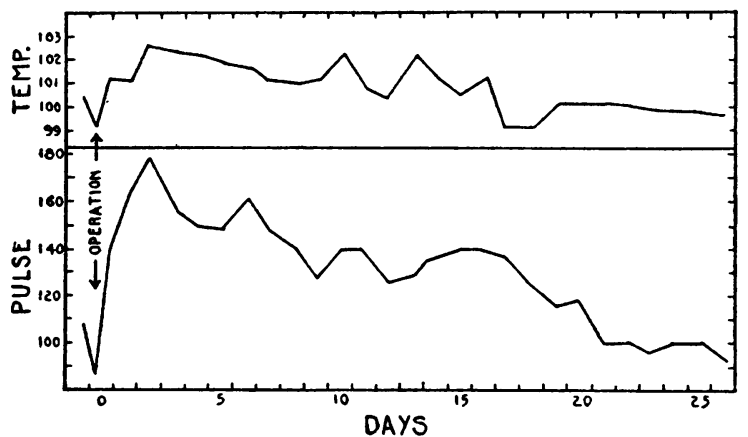

Fig. 1. Daily Maximum Temperature and Pulse of Patient D. K., During Rheumatic Recrudescence Following Splenectomy. manifestations was accompanied by leukocytosis and included pancarditis, polyarthritis, epistaxis, hematuria and pyrexia, symptomatically relieved by salicylates. In some, the recrudescences occurred shortly after splenectomy; in others, there was a brief symptom-free period. One illustrative record is presented in Table III and Figure 1. None of these recrudescences were accompanied by a rise in antistreptolysin titer.

\section{CASE HISTORIES}

$D$. K., Number 234004. The patient, a girl of seven, was known to have been rheumatic since the age of four. In February, 1932, she contracted pharyngitis which was followed by a prolonged rheumatic attack. The physical examination in October showed a well nourished girl in apparently good health. There was slight enlargement of the left side of the heart and a systolic murmur at the apex transmitted to the axilla. The leukocyte count was 6,050 with 55 per cent polymorphonuclears. The blood sedimentation rate, which was not reported until after operation, was $85 \mathrm{~mm}$. in one hour. Splenectomy was performed under ether anesthesia on October 11th. The operation took thirty minutes. There were a few adhesions around the upper pole of the spleen. No diffi- 
TABLE III

Clinical and laboratory findings in Patient $D . K$. during rheumatic recrudescence following splenectomy

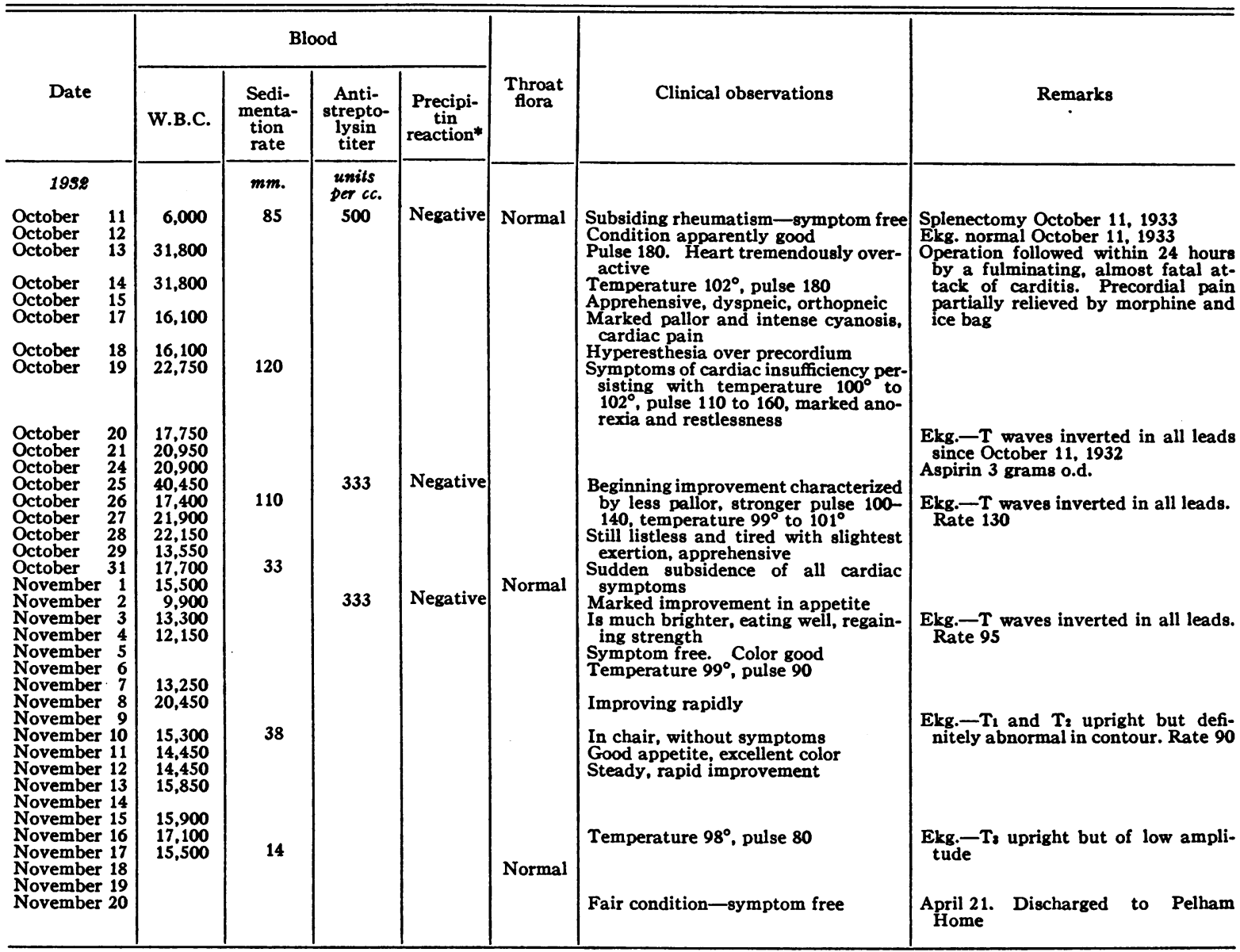

* Antigen used was hemolytic streptococcus nucleoprotein-fraction C19K.

culties were encountered, and the patient returned to the ward in good condition.

The first twelve hours after operation were not alarming. The pulse rate rose to 140 and the temperature to 101. The next day the picture was that of fulminating pancarditis. The patient complained of precordial pain, the pulse rose to 180 ; cyanosis became intense. For seven days her condition was critical. The temperature rose; drowsiness, dyspnea and orthopnea were extreme; the heart sounds became weak, pulse was almost imperceptible; cardiac signs suggested acute pericarditis; skin hyperesthesia developed over the precordial region. On October 18th she was digitalized, and on October 21st administration of aspirin was begun. On October 26th her condition changed abruptly. After being extremely ill with symptoms and signs of marked cardiac embarrassment she suddenly became comfortable. Cyanosis, pallor, nausea, cardiac pain, and drowsiness disappeared during a period of twelve hours. The intensity of the attack abated rapidly. The heart, which had been slightly enlarged and then increased tremendously in size follow- ing splenectomy, remained grossly enlarged in the lateral diameters at all levels with greatest enlargement in the left auricular zone. The electrocardiogram, interpreted as normal on admission, showed inversion of $T$ waves in all three leads on October 20th and October 25th. On November 9th, $T_{1}$ and $T_{2}$ had become upright but were of low amplitude and abnormal contour. She was transferred to The Pelham Home on November 21st where, because of her low myocardial reserve, it was found necessary to maintain bed rest for twelve months.

The clinical course of this patient's illness may be visualized in the accompanying temperature record, Figure 1. The laboratory findings are presented in Table III. From this record it is seen that although symptom-free, she had a high blood sedimentation rate and a high antistreptolysin titer at the time of operation. The rheumatic process was probably active although the 
patient was symptom-free when the spleen was removed. The immediate development of fulminating pancarditis was accompanied by a marked leukocytosis, rise in blood sedimentation rate, increased urinary excretion of erythrocytes and a slight drop in antistreptolysin titer. The attack lasted seventeen days and subsided abruptly, accompanied by a fall in blood sedimentation rate from $110 \mathrm{~mm}$. to $33 \mathrm{~mm}$. The electrocardiographic changes were in accord with the clinical findings of severe carditis.

\section{Examination of spleens}

Gross and microscopic examination and bacteriological cultures were made of the spleens immediately after removal. The cultures all remained sterile. The gross appearance of the spleens was essentially normal, and no differences were detected between the spleens of individuals who developed recrudescences and those who remained quiescent.

\section{SUM MARY}

Splenectomy did not permanently modify either the immune response or the character of the rheumatic recrudescence.

Nine out of twenty apparently quiescent rheumatic subjects developed recrudescences as a direct sequel to splenectomy.

All of these nine individuals had elevated antistreptolysin titers at the time of operation, and none of them showed any increase in titer during or after the recrudescence.

This shows that following operative manipulation of antibody-producing tissue during subsiding rheumatism, an exacerbation of symptoms may develop in the absence of further rise in antistreptolysin titer.

\section{DISCUSSION}

The authors have pointed out that the first phase of acute rheumatism is infection of the upper respiratory tract with hemolytic streptococcus. This organism usually disappears from the throat flora within a few days. Its subsequent history is unknown. There is evidence, however, that its disappearance from the pharyngeal mucosa does not mean that it has been eliminated from the body. Pure cultures of hemolytic streptococ- cus have been recovered by the authors from the tonsils of patients whose throat flora had been free of hemolytic streptococcus for a period of months. The agent recovered from the tonsils appeared identical with the organism which had been associated with the acute respiratory infec. tion some months prior to tonsillectomy. Furthermore, autopsy findings in an individual whose tonsils had been removed have also shown the presence of an active infectious agent weeks after its disappearance from the surface of the pharynx. In this patient, Hallahan (see (2) Plate 10, Figure 4 ), although the throat flora had been free of hemolytic streptococcus for several weeks before death, microscopic sections of the pharyngeal tissue showed a severe inflammatory reaction with streptococci present in typical chain formation. Furthermore, smears from the tracheal lymph nodes contained many degenerate forms which appeared to be streptococci. From the bacteriological and the histological findings it seems likely that streptococcus can maintain activity in tissues surrounding the upper respiratory tract long after its disappearance from the buccal mucosa.

The second phase of acute rheumatism is a symptom-free period about which nothing is known. This is followed by the third phase, the rheumatic attack which occurs coincidentally with the appearance of antibodies in the circulation. By the time the third phase begins, hemolytic streptococcus has usually disappeared from the pharyngeal mucosa. However, the persistence of high antistreptolysin titer values for months after the onset of a rheumatic attack is evidence for the long-continued presence of the corresponding antigen-presumably the infectious agent itself. During this period when the antistreptolysin titer is markedly elevated in the rheumatic subject there is usually clinical evidence of activity of the rheumatic process. The prolonged character of rheumatic disease and the parallel persistence of high antistreptolysin titers are in accord with the concept that the infectious agent is present.

In contrast to the typical rheumatic attack which consists of three distinct phases, another type of attack has been observed. This variety of recrudescence follows almost immediately after operative procedures in the upper respiratory tract, such as tonsillectomy or extraction of teeth. It may be associated with invasion of the blood stream 
since transient bacteremia following tonsillectomy has been observed (10). Prior to the splenectomies reported above, the authors had observed this type of rheumatic recrudescence only following trauma to the pharynx or buccal cavity. It had not followed other operative procedures or trauma elsewhere in the body. Appendicectomy in ten rheumatic subjects under observation produced no rheumatic symptoms although five of these individuals had active rheumatism at the time of operation. Eleven rheumatic subjects who had severe fractures remained free of rheumatic symptoms."

It was, therefore, not expected that recrudescences would develop following splenectomy. This operative procedure in non-rheumatic subjects is not followed by rheumatism. Since cultures of the spleens and the operative field were both sterile, blood stream invasion analogous to that following tonsillectomy need not be considered as a factor. The fact that not one of these postsplenectomy attacks was accompanied by a rise in antistreptolysin titer indicates that there was no activation of the immunity mechanism. In this respect these postoperative recrudescences differ strikingly from the typical rheumatic attack. Furthermore, they followed almost immediately after removal of the spleen, without the usual symptom-free period.

The mechanism of these rheumatic recrudescences following splenectomy must therefore be somewhat different from the normal or posttonsillectomy types. It has been pointed out above that these nine recrudescences all occurred in individuals with high antistreptolysin titers. Only three patients with titers above 100 units escaped postsplenectomy rheumatic symptoms, and none of the patients with low titers developed any rheumatic symptoms.

When the rheumatic subject has been free of streptococcus infection for a long period of time, the antistreptolysin titer is low and presumably the antibody producing tissues are quiescent. In such patients splenectomy produced no untoward results. In contrast, when rheumatic subjects have had fairly recent hemolytic streptococcus in-

4 One other rheumatic patient had a Pott's fracture a few days after contracting hemolytic streptococcus pharyngitis. Two weeks later she developed acute rheumatism with high antistreptolysin titer. fections and still have high antistreptolysin titers the spleens probably contain streptococcus products and are active in the production of antibody (8); In such patients splenectomy was followed by recrudescence.

In order to account for the occurrence of these postsplenectomy attacks, the following hypothesis has been formulated: that the spleen of the rheumatic subject when actively engaged in the production of antibodies to hemolytic streptococcus contains some substance which can be released into the circulation. This substance, whether of bacterial or human origin, damages certain mesodermal tissues either directly or indirectly. In the course of an ordinary rheumatic attack it is released gradually during the period of immune response of the antibody-producing tissues, and gives rise to symptoms over a long period of time. In the attacks induced by splenectomy, the material was liberated suddenly by operative manipulation, producing almost immediate symptoms. On the other hand, in quiescent rheumatic subjects whose titers were low, and whose spleens were presumably inactive insofar as antibody production was concerned, this substance was either not present or, if its action is indirect, did not give rise to a toxic derivative. The intensity of the recrudescences following splenectomy paralleled the activity of the antibody-producing organs, as indicated by the antistreptolysin titers. Under this hypothesis, manipulation of the "active" spleens released into the circulation some substance, presumably non-viable, which was effective in initiating the clinical manifestations of rheumatic fever. The nature of this substance remains to be determined.

\section{GENERAL CONCLUSIONS}

The findings presented in earlier papers of this series $(1,2)$ led to two conclusions. First, both influenza virus and one type of hemolytic streptococcus were ineffective in initiating recrudescences in a rheumatic colony. This strain of streptococcus did not produce soluble toxin, and although present in the throat flora was not associated with acute infection. Second, another type of hemolytic streptococcus was highly effective in initiating recrudescences in 14 out of 16 rheumatic members of this same colony. This strain 
was a strong toxin producer, was associated with acute infection of the upper respiratory tract and was a single serological type. In addition to infection with an effective strain of hemolytic streptococcus, two other factors contributed to the development and character of this epidemic of acute rheumatism. These factors were first, the disease pattern peculiar to each rheumatic subject, and second, the intensity of the immune response.

Next it was pointed out (3) that most strains of hemolytic streptococcus which are effective in producing acute rheumatism form soluble toxin and streptolysin and are indistinguishable from scarlatinal strains. Most of the strains associated with throat infections which are ineffective in initiating rheumatic attacks form little or no soluble toxin. This finding, in conjunction with earlier studies (11), indicates a close relationship between scarlet fever, acute rheumatism and toxinproducing strains of hemolytic streptococcus.

The findings presented in the fifth paper of the present series (4) demonstrated that neither active nor passive immunization to hemolytic streptococcus inhibited the development of the rheumatic process. The observations indicated that the development of rheumatic activity depends not only upon infection with an erythrogenic strain but also upon the host's immune response to such infection.

Next it was pointed out (5) that there is a close time relationship between the antistreptolysin rise and the onset of rheumatic activity. A small number of rheumatic subjects were observed to be infected with strains of hemolytic streptococcus which produced strong toxin and streptolysin, and nevertheless fail to develop a significant rise in antistreptolysin titer. These individuals also failed to develop a rheumatic attack. The authors interpret this fact to mean that in addition to infection with an effective strain, stimulation of the host sufficient to produce an antibody response is essential to initiation of rheumatic activity. It seemed that the character of the antibody response played a large part in determining the type of the rheumatic attack.

Finally, the observations made in the present paper indicate that in the patients who escaped postsplenectomy rheumatic recrudescences, the antibody-producing tissue was presumably quies- cent; and that in those patients who developed acute rheumatism following splenectomy, the antibody-producing tissue was probably in a state of activity. Likewise, as was already pointed out, in the subjects who escape recrudescences following infection with hemolytic streptococcus, the antibody-producing tissue presumably remains quiescent; and in those subjects who develop acute rheumatism following hemolytic streptococcus infection, the antibody-producing tissue is activated. These two sets of observations together show that acute rheumatism may follow either activation of the antibody-producing system by hemolytic streptococcus or operative manipulation of this system during the period in which it is producing immune bodies to hemolytic streptococcus.

It is the authors' conception that rheumatic disease is the result of the following sequence of events: (1) Infection with toxin-producing strains of hemolytic streptococcus initiates a process peculiar to rheumatic subjects; (2) In the course of this process a substance is released, presumably from the antibody producing tissues, which either directly or indirectly alters mesodermal structures. This substance is probably not the infecting organism, and at the present time there is no evidence to suggest that it is viable; (3) The release of this toxic substance seems to take place only when there is an immune response to hemolytic streptococcus.

In conclusion, the collected evidence indicates that activity of the rheumatic process depends not only upon effectiveness of the infecting strain of hemolytic streptococcus but also upon the intensity of the immune response of the rheumatic subject to this bacterial agent.

To the three nurses, Lucille Miller, Mary Kells and Ruth Colby, the care of the patients was entrusted. Dr. Edward J. Donovan performed the splenectomies. Dr. Lucille Moore and Miss Eleanor M. Kapp assisted the authors in many ways. The advice of Dr. Alphonse R. Dochez was invaluable. With the help of these associates and with the assistance of The W. K. Kellogg Foundation the authors have been able to conduct the present studies. 


\section{BIBLIOGRAPHY}

1. Coburn, A. F., and Pauli, R. H., Studies on the immune response of the rheumatic subject and its relationship to activity of the rheumatic process. II. Observations on an epidemic of influenza followed by hemolytic streptococcus infections in a rheumatic colony. J. Exper. Med., 1935, 62, 137.

2. Coburn, A. F., and Pauli, R. H., This series. III. Observations on the reactions of a rheumatic group to an epidemic infection with hemolytic streptococcus of a single type. J. Exper. Med., 1935, 62, 159.

3. Coburn, A. F., and Pauli, R. H., This series. IV. Characteristics of strains of hemolytic streptococcus effective and non-effective in initiating rheumatic activity. J. Clin. Invest., 1935, 14, 755.

4. Coburn, A. F., and Pauli, R. H., This series. V. Active and passive immunization to hemolytic streptococcus in relation to the rheumatic process. J. Clin. Invest., 1935, 14, 763.
5. Coburn, A. F., and Pauli, R. H., This series. VI. The significance of the rise of antistreptolysin level in the development of rheumatic activity. J. Clin. Invest., 1935, 14, 769.

6. Luckhardt, A. B., and Becht, F. C., The relation of the spleen to the fixation of antigens and the production of immune bodies. Am. J. Physiol., 1911, 28, 257.

7. Krumbhaar, E. B., Functions of the spleen. Physiol. Rev., 1926, 6, 160.

8. Topley, W. W. C., The rôle of the spleen in the production of antibodies. J. Path. and Bact., 1930, 33, 339.

9. Wollstein, M., Unpublished data.

10. Bartlett, F. H., and Pratt, J. S., Streptococci isolated from excised tonsils and posttonsillectomy blood cultures. Am. J. Dis. Child., 1931, 41, 285.

11. Coburn, A. F., The Factor of Infection in the Rheumatic State. Williams and Wilkins Company, Baltimore, 1931. 